\title{
What to Do When They're Eating for Two? A Case of Catheter-Directed Thrombolysis for Submassive Pulmonary Embolism in Pregnancy
}

Michael Radford, MD', Siraj Mithoowani, MD ${ }^{1}$, Michael Connolly, MD², Wendy Lim, MD, MSc ${ }^{1}$

${ }^{1}$ Department of Medicine, McMaster University, Hamilton, ON, Canada

${ }^{2}$ Department of Radiology, McMaster University, Hamilton ON, Canada

Author for correspondence: Wendy Lim, MD, MSc, FRCPC: limwp@mcmaster.ca

Received: 31 March 2020; Accepted after revision: 27 April 2020; Published: 26 March 2021.

DOI: http://dx.doi.org/10.22374/cjgim.v16i1.440

\begin{abstract}
A 33-year-old G7P0 female at 8 weeks gestation presented to the emergency department (ED) following a syncopal episode. She complained of chest pain and dyspnea, and had hemodynamic instability, which responded to intravenous fluids. Continued fluid resuscitation, supplemental oxygen, as well as therapeutic dose low molecular weight heparin (LMWH) were administered in the ED. Computed tomography (CT) pulmonary angiogram confirmed saddle pulmonary embolism (PE). After $12 \mathrm{~h}$ of continued chest pain and high oxygen requirements, a decision was made to use catheter-directed thrombolysis (CDT) involving alteplase with manual thrombus maceration in bilateral pulmonary arteries. There were no immediate hemorrhagic complications and follow-up fetal ultrasound demonstrated a normal viable intrauterine pregnancy. She clinically improved and was discharged on LMWH. Cesarean section was scheduled, and the patient delivered a healthy term infant at 37 weeks gestation without complications. Our case demonstrates that CDT may be a safe and effective treatment for submassive PE in pregnancy.
\end{abstract}

\section{RÉSUMÉ}

Une femme âgée de 33 ans et enceinte de huit semaines (G7P0) se présente aux urgences à la suite d'un épisode syncopal. Elle se plaint de douleurs thoraciques et de dyspnée et présente une instabilité hémodynamique qui répond aux solutés intraveineux. Une réanimation liquidienne continue, une oxygénothérapie ainsi qu'une dose thérapeutique d'héparine de faible poids moléculaire sont administrées aux urgences. L’angiographie pulmonaire par tomodensitométrie confirme une embolie pulmonaire en selle. Après 12 heures de douleurs thoraciques continues et de besoins élevés en oxygène, on décide d'utiliser la thrombolyse dirigée par cathéter (TDC) à l'aide de l'altéplase avec macération manuelle du thrombus dans les artères pulmonaires bilatérales. Il n’y a pas eu de complications hémorragiques immédiates et le suivi échographique du foetus a démontré une grossesse intra utérine normale et viable. Son état clinique s'est amélioré et elle a obtenu son congé sous héparine de faible poids moléculaire. Une césarienne a été planifiée et la patiente a accouché d'un enfant à terme et en bonne santé à 37 semaines de grossesse, sans complications. Notre cas démontre que la TDC peut être un traitement sûr et efficace de l'embolie pulmonaire submassive en cours de grossesse. 


\section{Case Report}

A 33-year-old female, 8 weeks pregnant (Gravida 7, Para 0), with past medical history significant for hypothyroidism, uterine leiomyomas, and seven spontaneous abortions (all $<20$ weeks' gestational age) presented to the emergency department (ED) with chest pain, right upper quadrant abdominal pain, and dyspnea. She had reported a brief syncopal episode on ambulation earlier that day. Medications included levothyroxine and prenatal vitamins. Family history was significant for systemic lupus erythematosus (SLE). In the ED, she was neurologically intact, appeared diaphoretic, and had an increased work of breathing. Vital signs demonstrated hypotension $(88 / 66 \mathrm{mmHg})$, tachycardia (126 beats per minute), and tachypnea ( 36 breaths per minute). Intravenous fluids were administered with an increase in systolic blood pressure to $100 \mathrm{mmHg}$, and $100 \%$ oxygen by facemask was applied, which improved the hypotension and hypoxia; however, tachycardia persisted.
Initial investigations included an electrocardiogram (ECG) demonstrating sinus tachycardia, S1Q3T3 phenomenon, and evidence of right heart strain (Figure 1). Initial high-sensitivity troponin I was $126 \mathrm{ng} / \mathrm{L}$ (normal < $30 \mathrm{ng} / \mathrm{L}$ ), and bedside point of care ultrasound demonstrated right ventricular (RV) dysfunction. A computed tomography (CT) scan of the thorax demonstrated a pulmonary embolism (PE) with a large clot burden involving distal left and right main pulmonary arteries, and extending into the lobar arteries (Figure 2).

Formal transthoracic echocardiogram demonstrated severe RV enlargement, moderately to severely impaired RV systolic function, and akinesia of the RV free wall. RV systolic pressure (RVSP) was 29 $\mathrm{mmHg}$ and left ventricular ejection fraction (LVEF) was 60-65\%. The diagnosis of submassive PE was confirmed. Therapeutic dose low molecular weight heparin (LMWH; dalteparin $200 \mathrm{IU} / \mathrm{kg}=$ $18,000 \mathrm{IU}$ ) was administered subcutaneously, and the patient was transferred to the intensive care unit (ICU). Repeat troponin rose

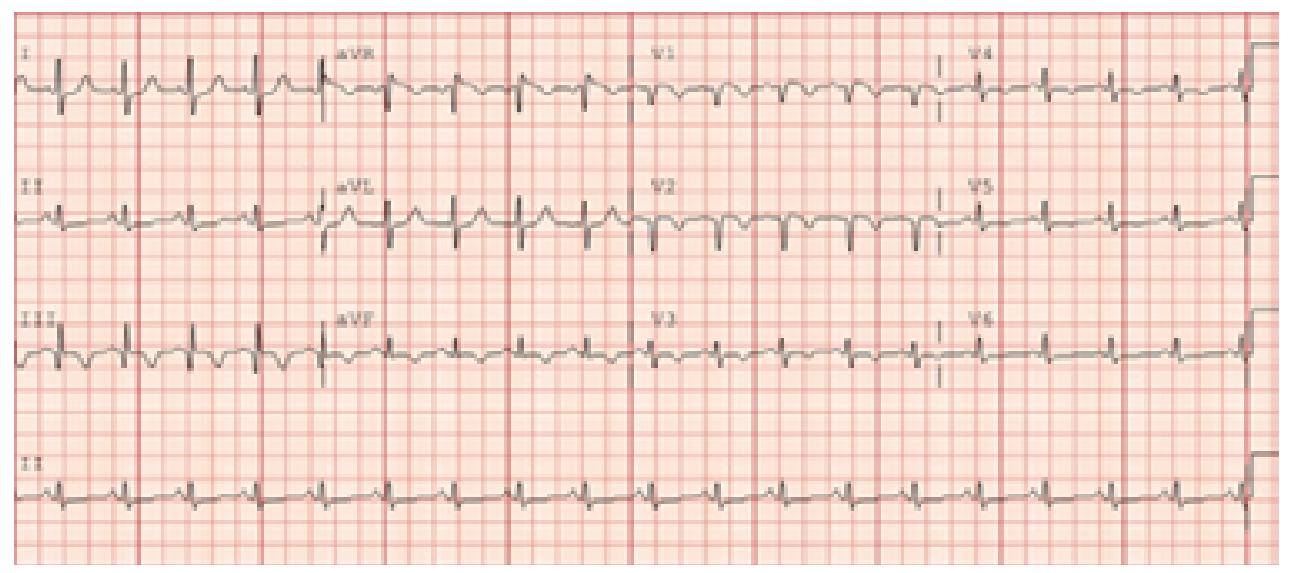

Figure 1. Electrocardiogram demonstrating $\mathrm{S}_{1} \mathrm{Q}_{3} \mathrm{~T}_{3}$, sinus tachycardia and right heart strain on initial presentation.

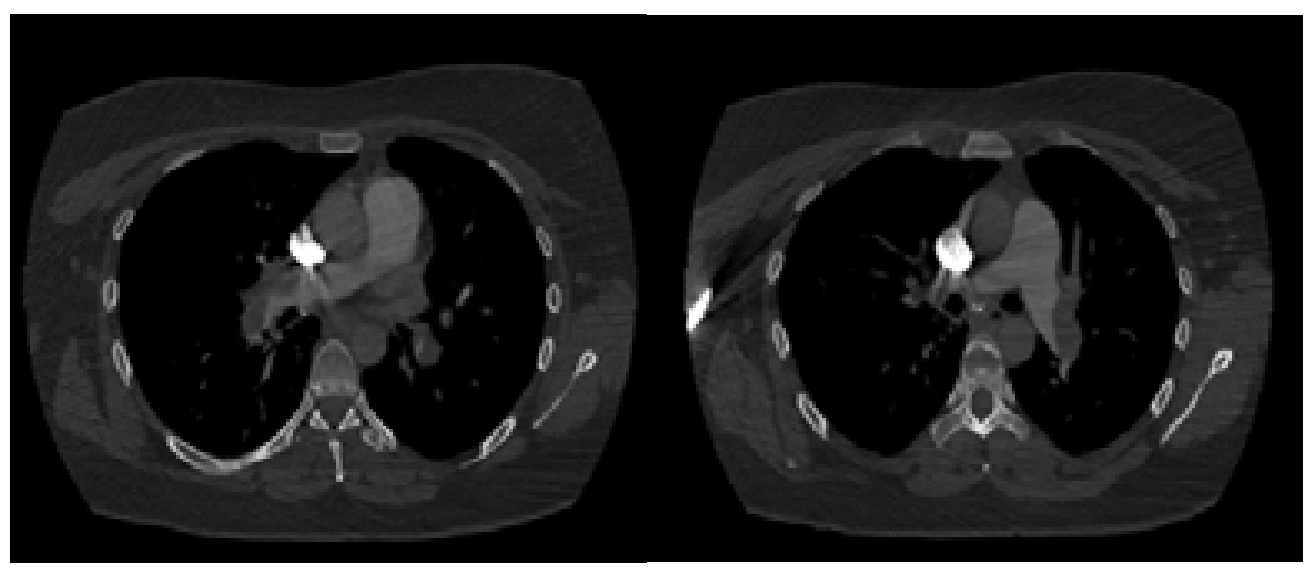

Figure 2. CT PE at diagnosis demonstrating the clot burden. CT = computed tomography; $\mathrm{PE}=$ pulmonary embolism. 
to $1335 \mathrm{ng} / \mathrm{L}$. Despite receiving multiple doses of morphine for analgesia, she continued to complain of abdominal pain, pleuritic chest pain, and dyspnea. Supplemental oxygen was titrated down from $\mathrm{FiO} 2100$ to $40 \%$ by facemask to maintain $\mathrm{SaO}_{2}$ above $95 \%$. Blood pressure remained stable at 100-110/80-90 mm Hg.

On subsequent evaluation, her symptoms persisted despite initial treatment with anticoagulants. Weighing the persistence of symptoms in a patient with submassive PE against a low bleeding risk profile, the decision was made to proceed with catheterdirected thrombolysis (CDT). After obtaining informed consent outlining risks of mortality (1\%), major bleeding (8-10\%), and $5-10 \%$ risk of fetal loss, she underwent CDT on day one of her hospital admission. Through a $5 \mathrm{~F}$ vascular sheath in the right common femoral vein, $5 \mathrm{mg}$ of tissue plasminogen activator (tPA; Alteplase) was laced in each main pulmonary artery (total bolus of $10 \mathrm{mg}$ ) via a $5 \mathrm{~F}$ pigtail catheter. The tPA sat within the thrombus for $5 \mathrm{~min}$, followed by manual maceration of the thrombus. The pigtail was then pulled back into the main pulmonary artery for continuous tPA infusion of $1 \mathrm{mg} / \mathrm{h}(0.01 \mathrm{mg} / \mathrm{h}$ at $100 \mathrm{~mL} / \mathrm{h})$. Heparin was simultaneously infused at $500 \mathrm{IU} / \mathrm{h}(40 \mathrm{IU} / \mathrm{mL}$ at $12.5 \mathrm{~mL} / \mathrm{h}$ ) via the right common femoral vein sheath to prevent thrombus formation on the catheter and provide subtherapeutic anticoagulation. Efforts were made to limit the radiation dose to the fetus during the procedure by minimizing the angiographic runs, appropriate collimation, and decreasing the pulse rate of fluoroscopy to 2-3 pulses per second. After $7 \mathrm{~h}$ of tPA infusion, there was marked clinical improvement, with $\mathrm{FiO} 2$ requirements decreasing to $4 \mathrm{~L} / \mathrm{min}$ by nasal prongs, heart rate decreasing to $112 \mathrm{bpm}$, and resolution of the chest pain and dyspnea. The tPA infusion was discontinued, the catheter and sheath were removed and a therapeutic heparin infusion was initiated. There were no hemorrhagic complications. Symptoms of chest and abdominal pain resolved, and supplemental oxygen was discontinued. Fetal ultrasound on day 3 of admission demonstrated a single viable intrauterine pregnancy. Given the patient's history of recurrent pregnancy loss, antiphospholipid antibody testing was ordered and returned negative (anti-cardiolipin IgG and beta2-gycloprotein IgG both $<5$ units $/ \mathrm{mL}$ ), which supported the belief that her previous fetal losses were secondary to leiomyomas. She was transitioned to tinzaparin 18,000 IU SC daily and discharged home 7 days after her initial presentation with close follow-up arranged.

She was followed throughout her pregnancy where she continued to be asymptomatic with no episodes of major bleeding, recurrent venous thromboembolism (VTE), or pregnancy complications. She remained on tinzaparin throughout the remainder of her pregnancy and planned delivery for 37 weeks gestation. Her last dose of tinzaparin was administered $24 \mathrm{~h}$ prior to delivery. She delivered a healthy baby boy by caesarian section without any immediate complications.

\section{Discussion}

VTE in pregnancy is one of the leading causes of maternal mortality with close to one in 10 maternal deaths attributed to antepartum and postpartum PE. ${ }^{1}$ The clinical presentation of $\mathrm{PE}$ is variable, and acute complications are similar to those seen in the nonpregnant population. ${ }^{2}$ In pregnancy, therapeutic dose LMWH is the standard of care for the management of VTE (acute submassive/low-risk PE and deep vein thrombosis). ${ }^{3}$ When patients present with massive $\mathrm{PE}$ (Table 1), or if anticoagulation alone fails to improve the patient's condition, thrombolysis can be considered. ${ }^{4}$

Table 1. American Heart Association classification of pulmonary embolism ${ }^{4}$

\begin{tabular}{|c|c|}
\hline Risk stratification of acute PE & Criteria (1 or more) \\
\hline Massive & $\begin{array}{l}\text { - Sustained hypotension (systolic BP }<90 \mathrm{~mm} \mathrm{Hg} \text { for } 15 \text { min or requiring ionotropic } \\
\text { support) } \\
\text { - Pulselessness } \\
\text { - Sustained heart rate }<40 \text { BPM with signs/symptoms of shock }\end{array}$ \\
\hline Submassive & $\begin{array}{l}\text { - Systolic BP }>90 \mathrm{~mm} \mathrm{Hg} \text { and RV dysfunction or myocardial necrosis defined by: } \\
\text { - RV dilation (apical four-chamber RV diameter divided by LV diameter }>0.9 \text { ) or RV } \\
\text { systolic dysfunction on echocardiography } \\
\text { - RV dilation (four-chamber RV diameter divided by LV diameter }>0.9 \text { ) on CT } \\
\text { - Elevation of BNP ( }>90 \mathrm{pg} / \mathrm{mL} \text { ) or N-terminal pro-BNP }(>500 \mathrm{pg} / \mathrm{mL} \text { ) } \\
\text { - ECG changes (new complete or incomplete right bundle-branch block, anteroseptal } \\
\text { ST elevation or depression, or anteroseptal T-wave inversion) } \\
\text { - Elevation of troponin I (>0.4 } \mathrm{ng} / \mathrm{mL} \text { ) or troponin T }(>0.1 \mathrm{ng} / \mathrm{mL} \text { ) }\end{array}$ \\
\hline Low-risk & - Normotensive, normal biomarkers, no RV dysfunction on imaging \\
\hline
\end{tabular}

PE pulmonary embolism; BP, blood pressure; BPM, beats per minute; RV, right ventricle; LV, left ventricle; BNP, B-type natriuretic peptide; CT, computed tomography; ECG, electrocardiogram. 
Thrombolysis, either systemic with the use of fibrinolytic agents, or catheter-directed using pharmacologic and/or mechanical methods have been evaluated in nonpregnant patients, largely for massive PE. ${ }^{5}$ Whether to administer systemic thrombolysis for submassive PE remains controversial. A large, prospective, randomized control trial evaluating the impact of thrombolytic therapy on the long-term outcome of submassive PE showed that treatment with tenecteplase did not affect long-term mortality rates and did not significantly reduce functional limitations or RV dysfunction. Findings were limited by loss to follow-up, findings of late death not being centrally adjudicated, and the absence of clinical and echocardiographic evaluation on all survivors. ${ }^{6}$ Multiple prospective trials such as ULTIMA, PERFECT, and SEATTLEII have investigated the use of CDT for submassive PE. Results were promising, demonstrating improvements in surrogate outcomes such as reduction in pulmonary artery pressures. Drawing conclusions from these trials is challenging due to methodological flaws, including the use of surrogate outcomes, lack of long-term follow-up, and low statistical power. ${ }^{7-9}$ These studies excluded pregnant women, so evidence supporting CDT in this population is limited to case reports. ${ }^{10-16}$

We identified seven published cases reporting CDT for PE in pregnancy with four being in submassive PE (Table 2). ${ }^{10-16}$ Five cases involved treatment with tPA and two with urokinase. The total dose administered and the duration of administration of the thrombolytic agent varied with each case. Furthermore, multiple cases involved concurrent additional therapies, particularly mechanical thrombectomy, prior to the administration of thrombolytic agents. Of the case reports involving CDT, there was only one major bleed reported. There were no maternal deaths, and there was only one fetal loss, which the authors believed was not associated with the treatment. ${ }^{10-16}$

Systemic thrombolysis in pregnancy carries the risks of maternal bleeding and fetal loss. In a recent review of pregnant patients treated with systemic thrombolysis, there was a $12.5 \%$ risk of major maternal bleeding and a $8.3 \%$ risk of fetal demise. ${ }^{17}$ The risk of bleeding with CDT is considered to be lower than with systemic thrombolysis because a lower dose of tPA is administered. With systemic thrombolysis, a typical dose of tPA to treat PE is $100 \mathrm{mg}$ compared to CDT, where standard infusion rates of 1-2 $\mathrm{mg} / \mathrm{h}$ result in a cumulative dose of approximately $15-30$ mg. ${ }^{18,19}$ Although radiation exposure is an additional concern in pregnant patients, treatment totals were estimated to be approximately $118.8 \mathrm{mGy}$, which is equivalent to approximately six to seven CT scans of the thorax. The dose of radiation to the fetus is estimated to be $<1.4 \mathrm{mGy}$ (approximated by $0.2 \mathrm{mGy}$ dose per CT chest), which is significantly lower than the limit of $50 \mathrm{mGy}$, which, in turn, is associated with an increased risk of fetal loss and abnormalities. ${ }^{20}$

We present a case of successful management of submassive $\mathrm{PE}$ in the first trimester of pregnancy with CDT. The optimal treatment of submassive PE is controversial. Current treatment guidelines recommend anticoagulation alone as the initial mode of treatment. In our case, the persistence of hypoxia and

Table 2. Summary of case reports of catheter-directed thrombolysis in pregnant women with submassive PE

\begin{tabular}{|c|c|c|c|c|c|c|}
\hline Author & $\begin{array}{l}\text { PE } \\
\text { classification }\end{array}$ & $\begin{array}{c}\text { Weeks' } \\
\text { gestation }\end{array}$ & Treatment & $\begin{array}{l}\text { Maternal } \\
\text { outcome }\end{array}$ & $\begin{array}{c}\text { Fetal } \\
\text { outcome }\end{array}$ & Note \\
\hline $\begin{array}{l}\text { Krishnamurthy } \\
\text { et al. } \\
\text { (1999) }\end{array}$ & Submassive & $382 / 7$ & $\begin{array}{l}\text { Initial treatment with } \\
8,000 \mathrm{mg} \text { of IV UHF + } \\
1000 \mathrm{mg} / \mathrm{h} \text { infusion. } \\
2,200 \mathrm{units} / \mathrm{kg} \text { UK } \\
\text { bolus + infusion of } \\
2,200 \text { units/kg/h for } \\
24 \mathrm{~h} \text {. IV UFH at } 500 \\
\text { units/h and continued } \\
\text { for } 10 \text { days with aPTT } \\
\text { target } 60-80 \text { s. Heparin } \\
15,000 \text { U SC BID. }\end{array}$ & $\begin{array}{l}\text { No major } \\
\text { bleeding } \\
\text { V/Q normal } 6 \\
\text { weeks post CDT. }\end{array}$ & $\begin{array}{l}\text { Delivered at } \\
382 / 7 \text { weeks } \\
\text { following } \\
\text { elective } \\
\text { induction of } \\
\text { labor. }\end{array}$ & $\begin{array}{l}\text { Large azygos vein in } \\
\text { place of IVC. Previous } \\
\text { oral contraceptive pill } \\
\text { provoked DVT. Family } \\
\text { history of mesenteric } \\
\text { artery thrombosis. } \\
\text { Superficial vein } \\
\text { thrombosis in early } \\
\text { pregnancy. }\end{array}$ \\
\hline $\begin{array}{l}\text { Sofocleous } \\
\text { et al. } \\
\text { (2001) }\end{array}$ & Submassive & 15 & $\begin{array}{l}\text { Initial heparin infusion. } \\
\text { Balloon embolectomy } \\
\text { and mechanical } \\
\text { thrombectomy } \\
\text { followed. CDT of } 10 \mathrm{mg} \\
\text { r-tPA toright pulmonary } \\
\text { artery }+12 \mathrm{~h} \text { at } 2 \mathrm{mg} / \mathrm{h} \text {. }\end{array}$ & $\begin{array}{l}\text { Hemoptysis post } \\
\text { initial heparin } \\
\text { infusion. No } \\
\text { major bleeding } \\
\text { with tPA. } \\
\text { Embolus absent } \\
\text { on follow-up CT. }\end{array}$ & $\begin{array}{l}\text { Fetal demise } \\
24 \text { h post tPA. }\end{array}$ & \\
\hline
\end{tabular}




\begin{tabular}{|c|c|c|c|c|c|c|}
\hline $\begin{array}{l}\text { Pick } \\
\text { (2015) }\end{array}$ & Submassive & 33 & $\begin{array}{l}\text { One dose of LMWH } \\
\text { (dose not stated). } 6 \mathrm{mg} \\
\text { bolus of tPA in each } \\
\text { infusion catheter plus } \\
\text { continuous infusion at } \\
0.5 \mathrm{mg} / \mathrm{h} \text { following for } \\
22 \mathrm{~h} \text {. IV UFH infusion } \\
\text { of } 2300 \text { units/h was } \\
\text { maintained throughout } \\
\text { the procedure. IVC } \\
\text { filter post CDT for } \\
\text { prevention prior to } \\
\text { delivery. Therapeutic } \\
\text { enoxaparin during } \\
\text { hospitalization and on } \\
\text { discharge. Subsequent } \\
\text { CDT of DVT. }\end{array}$ & $\begin{array}{l}\text { Complete } \\
\text { resolution on } \\
\text { pulmonary } \\
\text { arteriography } \\
22 \mathrm{~h} \text { after } \\
\text { treatment with } \\
\text { normal perfusion } \\
\text { bilaterally. } \\
\text { Preeclampsia } \\
\text { with severe } \\
\text { features post-op } \\
\text { day } 11 .\end{array}$ & $\begin{array}{l}\text { Medically } \\
\text { induced } \\
\text { labor at } \\
\text { approximately } \\
35 \text { weeks }\end{array}$ & $\begin{array}{l}\text { Concurrent right femoral } \\
\text { DVT. } \\
\text { Thrombophilia } \\
\text { testing demonstrated } \\
\text { Protein S deficiency } \\
\text { and homozygous } \\
\text { methylenetetrahydrofolate } \\
\text { reductase C677T } \\
\text { mutation was discovered } \\
\text { after discharge. }\end{array}$ \\
\hline $\begin{array}{l}\text { O'Keeffe et al. } \\
\text { (2008) }\end{array}$ & Submassive & 38 & $\begin{array}{l}\text { Thrombus } \\
\text { fragmentation with } \\
\text { deferred catheter- } \\
\text { directed lysis } 3 \text { days } \\
\text { postpartum. Initial } 50 \\
\text { mg tPA over } 3 \mathrm{~h} \text { into } \\
\text { left and right lung, } \\
\text { followed by } 1 \mathrm{mg} / \mathrm{h} \\
\text { into left pulmonary } \\
\text { artery and UFH at } 500 \\
\text { U/h for } 24 \mathrm{~h} \text {. LMWH } 6 \mathrm{~h} \\
\text { postpartum. }\end{array}$ & $\begin{array}{l}\text { Episiotomy } \\
\text { hematoma } \\
\text { requiring surgical } \\
\text { evacuation } \\
\text { following UFH } \\
\text { and continuous } \\
\text { tPA. Complete } \\
\text { resolution of } \\
\text { emboli } 24 \mathrm{~h} \text { post } \\
\text { tPA. }\end{array}$ & $\begin{array}{l}\text { Spontaneous } \\
\text { vaginal } \\
\text { delivery. }\end{array}$ & $\begin{array}{l}\text { Superficial phlebitis at } \\
32 \text { weeks treated with } \\
\text { acetaminophen. Left } \\
\text { common femoral vein } \\
\text { DVT at presentation. } \\
6 \text { weeks post-partum } \\
\text { discovered to have } \\
\text { tubulocystic and } \\
\text { papillary clear cell } \\
\text { ovarian cancer. }\end{array}$ \\
\hline $\begin{array}{l}\text { Garbarino } \\
\text { et al. } \\
\text { (2017) }\end{array}$ & Massive & 33 & $\begin{array}{l}\text { Initial treatment } \\
\text { with oral ASA and } \\
\text { Heparin. } 2 \mathrm{mg} \text { tPA were } \\
\text { injected into each PA, } \\
\text { then continuous t-PA } \\
\text { infusion of } 1.2 \mathrm{mg} / \mathrm{h} \text { for } \\
17 \mathrm{~h} \text {. Heparin infusion } \\
\text { at a rate of } 500 \text { units/h } \\
\text { was continued during } \\
\text { this time. Enoxaparin } \\
\mathrm{SC} \text { on discharge. }\end{array}$ & $\begin{array}{l}\text { No major } \\
\text { bleeding } \\
\text { described, } \\
\text { improvement in } \\
\text { cardiac function } \\
\text { post treatment. }\end{array}$ & $\begin{array}{l}\text { Normal } \\
\text { intrauterine } \\
\text { pregnancy } \\
\text { at } 33 \text { weeks' } \\
\text { gestation } \\
\text { at time of } \\
\text { discharge. }\end{array}$ & \\
\hline $\begin{array}{l}\text { Bechtel } \\
(2005)\end{array}$ & Massive & 30 & $\begin{array}{l}\text { IV Heparin infusion + } \\
\text { IVC filter initially. } 12 \\
\text { mg tPA bolus. } 0.7 \mathrm{mg} / \mathrm{h} \\
\text { tPA infused into distal } \\
\text { right pulmonary artery } \\
\text { for } 5 \mathrm{~h} \text {. Peripheral IV } \\
\text { heparin was restarted } \\
\text { after the tPA infusion } \\
\text { discontinued. }\end{array}$ & & $\begin{array}{l}\text { Uncomplicated } \\
\text { delivery at } 38 \\
\text { weeks. }\end{array}$ & $\begin{array}{l}\text { Concurrent large } \\
\text { femeropopliteal and } \\
\text { peroneal vein DVT. }\end{array}$ \\
\hline
\end{tabular}




\begin{tabular}{|c|c|c|c|c|c|c|}
\hline $\begin{array}{l}\text { Weinberg } \\
\text { et al. } \\
\text { (2011) }\end{array}$ & Massive & 31 & $\begin{array}{l}\text { Placed on ECMO after } \\
\text { delivery. 30,000 IU UK } \\
\text { combined with local } \\
\text { suction embolectomy. } \\
\text { Continuous 100,000 } \\
\text { IU/h infusion for } 24 \\
\text { h following. IVC filter } \\
\text { placed temporarily } \\
\text { and removed when } \\
\text { INR therapeutic was } \\
\text { initiated. Long-term } \\
\text { Warfarin therapy. }\end{array}$ & $\begin{array}{l}\text { Postpartum } \\
\text { bleeding of } \\
1000 \mathrm{cc} \text {. Right } \\
\text { ventricular size } \\
\text { and function } \\
\text { and pulmonary } \\
\text { artery pressures } \\
\text { normalized } 8 \\
\text { months post } \\
\text { discharge. }\end{array}$ & $\begin{array}{l}\text { Premature } \\
\text { delivery at } 31 \\
\text { weeks with } \\
\text { thriving child } \\
\text { on follow-up. }\end{array}$ & $\begin{array}{l}\text { Postpartum pulmonary } \\
\text { embolism during } \\
\text { previous pregnancy } \\
\text { treated with } 6 \text { months of } \\
\text { warfarin. Enoxaparin } 40 \\
\text { mg SC Daily prophylaxis } \\
\text { starting second trimester } \\
\text { of current pregnancy. } \\
\text { Concurrent lower } \\
\text { extremity DVT on } \\
\text { presentation. }\end{array}$ \\
\hline
\end{tabular}

IV intravenous; UK, Urokinase; UFH, unfractionated heparin; aPTT, activated partial thromboplastin time; V/Q, ventilation perfusion; CDT, catheter-directed thrombolysis; IVC, inferior vena cava; DVT, deep vein thrombosis; tPA, tissue plasminogen activator; CT, computed tomography; LMWH, low molecular weight heparin; SC, subcutaneous; IV, intravenous; IU, international units.

"Authors classify pulmonary embolism as massive, but based on American Heart Association guidelines, we reclassified it as submassive PE.

chest pain despite therapeutic dose anticoagulation, alongside significant RV dysfunction and elevated troponin levels prompted the consideration of thrombolysis. The reduced systemic dose of fibrinolytic drugs, minimal radiation exposure, and local procedural expertise made CDT an attractive option over systemic thrombolysis. CDT was performed successfully with no adverse effects to the mother or the fetus.

\section{Conclusions}

There is minimal data comparing systemic thrombolysis with CDT for the treatment of submassive PE in pregnancy. The literature published to date supports that CDT is safe in pregnancy but is limited to case reports. The optimal interventional technique is unknown. However, there is a biologic rationale to limiting systemic exposure to fibrinolytic agents in pregnancy. Our case adds to the extremely limited body of literature on the use of CDT in pregnancy and demonstrates that $\mathrm{CDT}$ in an appropriately selected patient can lead to a favorable clinical outcome for both mother and fetus.

\section{Conflicts of Interest}

This project did not receive any specific funding. Michael Radford and Michael Connolly do not have any commercial disclosures. Siraj Mithoowani received honoraria from Leo Pharma. Wendy Lim has received consulting fees from Pfizer Canada and Leo Pharma, and received honoraria for continuing her medical education from Alexion Pharmaceuticals, BMS-Pfizer Alliance, Fresenius, Leo Pharma, Novartis, Pfizer Canada, Pharmacosmos, and Portola Pharmaceuticals.

\section{References}

1. Hirshberg A, Srinivas SK. Epidemiology of maternal morbidity and mortality. Semin Perinatol. 2017;41(6):332-7. http://dx.doi.org/10.1053/j. semperi.2017.07.007
2. Chan WS, Ray JG, Murray S, et al. Suspected pulmonary embolism in pregnancy. Arch Intern Med. 2002;162(10):1170. http://dx.doi.org/10.1001/ archinte.162.10.1170

3. Bates SM, Rajasekhar A, Middeldorp S, et al. American Society of Hematology 2018 guidelines for management of venous thromboembolism: Venous thromboembolism in the context of pregnancy. Blood Adv. 2018;2(22):3317-59. http://dx.doi.org/10.1182/bloodadvances.2018024802

4. Jaff MR, McMurtry MS, Archer SL, et al. Management of massive and submassive pulmonary embolism, iliofemoral deep vein thrombosis, and chronic thromboembolic pulmonary hypertension: A scientific statement from the american heart association. Circulation. 2011;123(16):1788-830. http://dx.doi.org/10.1161/CIR.0b013e318214914f

5. Hao Q, Dong BR, Yue J, et al. Thrombolytic therapy for pulmonary embolism. Cochrane Database Syst Rev. 2015;2015(9). http://dx.doi .org/10.1002/14651858.CD004437.pub4

6. Konstantinides SV, Vicaut E, Danays T, et al. Impact of thrombolytic therapy on the long-term outcome of intermediate-risk pulmonary embolism. J Am Coll Cardiol. 2017;69(12):1536-44. http://dx.doi.org/10.1016/j .jacc.2016.12.039

7. Kucher N, Boekstegers P, Müller OJ, et al. Randomized, controlled trial of ultrasound-assisted catheter-directed thrombolysis for acute intermediaterisk pulmonary embolism. Circulation. 2014;129(4):479-86. http://dx.doi .org/10.1161/CIRCULATIONAHA.113.005544

8. Kuo WT, Banerjee A, Kim PS, et al. Pulmonary embolism response to fragmentation, embolectomy, and catheter thrombolysis (PERFECT). Chest. 2015;148(3):667-73. http://dx.doi.org/10.1378/chest.15-0119

9. Piazza G, Hohlfelder B, Jaff MR, et al. A prospective, single-arm, multicenter trial of ultrasound-facilitated, catheter-directed, low-dose fibrinolysis for acute massive and submassive pulmonary embolism: The SEATTLE II study. JACC Cardiovasc Interv. 2015;8(10):1382-92. http://dx.doi.org/10.1016/ j.jcin.2015.04.020

10. Krishnamurthy P, Martin CB, Kay HH, et al. Catheter-directed thrombolysis for thromboembolic disease during pregnancy: A viable option. J Matern Neonatal Med. 1999;8(1):24-7. http://dx.doi .org/10.3109/14767059909063149

11. Pick J, Berlin D, Horowitz J, et al. Massive pulmonary embolism in pregnancy treated with catheter-directed tissue plasminogen activator. A A Case Rep. 2015;4(7):91-4. http://dx.doi.org/10.1213/XAA.0000000000000128

12. Garbarino A, Miller N, Tatem G. Successful catheter-directed thrombolysis for pulmonary embolism during pregnancy. Am J Respirol Crit Care Med. 2017;195:A6212. http://dx.doi.org/10.1164/ajrccm-conference.2017 .195.1_MeetingAbstracts.A6212 
13. O'Keeffe SA, McGrath A, Ryan JM, et al. Management of a massive pulmonary embolism in a pregnant patient with mechanical fragmentation followed by delayed catheter-directed thrombolysis in the early postpartum period. J Matern Neonatal Med. 2008;21(8):591-4. http://dx.doi .org/10.1080/14767050802165604

14. Weinberg L, Kay C, Liskaser F, et al. Successful treatment of peripartum massive pulmonary embolism with extracorporeal membrane oxygenation and catheter-directed pulmonary thrombolytic therapy. Anaesth Intensive Care. 2011;39(3):486-91. http://dx.doi.org/10.1177/0310057x1103900323

15. Sofocleous CT, Hinrichs C, Bahramipour P, et al. Percutaneous management of life-threatening pulmonary embolism complicating early pregnancy [3]. J Vasc Interv Radiol. 2001;12(11):1355-6. http://dx.doi.org/10.1016/ S1051-0443(07)61566-8

16. Bechtel JJ, Mountford MC, Ellinwood WE. Massive pulmonary embolism in pregnancy treated with catheter fragmentation and local thrombolysis.
Obstet Gynecol. 2005;106(5):1158-60. http://dx.doi.org/10.1097/01 .AOG.0000164058.63244.9c

17. Ho VT, Dua A, Lavingia K, et al. Thrombolysis for venous thromboembolism during pregnancy: A literature review. Vasc Endovascular Surg. 2018;52(7):527-34. http://dx.doi.org/10.1177/1538574418777822

18. Kuo WT. Endovascular therapy for acute pulmonary embolism. J Vasc Interv Radiol. 2012;23(2):167-179.e4. http://dx.doi.org/10.1016/j.jvir.2011.10.012

19. Sharifi M, Bay C, Skrocki L, et al. Moderate pulmonary embolism treated with thrombolysis (from the "mOPETT" trial). Am J Cardiol. 2013;111(2):273-7. http://dx.doi.org/10.1016/j.amjcard.2012.09.027

20. McCollough CH, Schueler BA, Atwell TD, et al. Radiation exposure and pregnancy: When should we be concerned? RadioGraphics. 2007;27:909-18. http://dx.doi.org/10.1016/s0098-1672(08)79159-8 